\title{
ANALISIS ASPEK PERPAJAKAN ATAS USAHA JASA KONSTRUKSI DALAM PEMENUHAN KEWAJIBAN PERPAJAKAN
}

\author{
Bayu Sarjono* \\ bayu.sarjono@staff.ubaya.ac.id
}

\section{Abstract}

Taxes is one of the most important sources of national income, which is taxes are a main sources in sustaining government and development in a country. Indonesia is a developing country so it is not in spite of the various infrastructure development. In view of its development, the construction sector contributed substantially as the drivers of national economic growth.

This study using qualitative research with the aim to analyze aspects of the income tax and value added tax on construction industry. Aspects of taxation to the construction businesses has characteristics with other business. The method of recognition of income used is the percentage of completion method.

The results of research showed that revenue from construction businesses income tax withholding has been made final income tax by the Treasurer, while the income derived from procurement of goods this failure code in the remittance of taxes, so have to make a balance transfer application. In the Value Added Tax, taxable person/entrepreneurs are overpaid VAT because the entire transaction was opposed to VAT collector.

Keywords: Taxes, Construction Industry, Income Tax, Value Added Tax, The Percentage of Completion Method.

\section{Pendahuluan}

Kemandirian suatu bangsa, dapat diukur dari kemampuan bangsa untuk melaksanakan dan membiayai pembangunan sendiri. Bagi negara, pajak adalah salah satu sumber penerimaan negara yang sangat penting, dimana pajak merupakan suatu pilar utama dalam menopang jalannya pe- merintahan dan pembangunan di suatu negara. Keuangan yang ditanggung oleh negara untuk membiayai pengeluaran rutin maupun pengeluaran untuk pembangunan tidaklah sedikit dan tidak mungkin untuk ditanggung oleh pemerintah sendiri. Oleh karena itu pemaksimalan sumber-sumber penerimaan negara sangat dibutuhkan.

* Dosen Program Studi Perpajakan, Politeknik Ubaya, Surabaya. 
Indonesia merupakan negara berkembang sehingga tidak terlepas dari berbagai pembangunan infrastruktur, baik itu pembangunan jalan, gedung, perumahan, sarana dan prasarana lainnya. Proyek-proyek yang ada dalam konstruksi itu sendiri sebagian diisi oleh proyek pemerintah dan sisanya diperoleh dari proyek swasta. Dilihat dari perkembangannya, sektor konstruksi tidak saja berdampak pada kehidupan ekonomi, namun juga berimbas positif bagi kehidupan sosial masyarakat. Hubungan antar kemajuan ekonomi dan sosial masyarakat dapat dilihat dari hasil kerja para pelaku industri konstruksi. Keberadaan berbagai macam hasil pekerjaan konstruksi seperti sekolah, pusat bisnis, gedung pemerintahan, jembatan, hingga jalan raya akan menciptakan gerak perokonomian sekaligus penopang kehidupan sosial-budaya sebuah bangsa.

Di sisi lain, apa pun bentuk usahanya termasuk di bidang konstruksi atau jasa, tidak bisa lepas dari pajak. Pajak merupakan sumber penerimaan yang paling besar, karena APBN sebagian besar dibiayai oleh pajak. Pajak juga memiliki potensi paling besar setiap tahunnya karena pajak meningkat seiring dengan laju pertumbuhan penduduk, perekonomian, dan stabilitas politik suatu negara.

Sejak tahun 2001, pengenaan pajak atas penghasilan dari usaha jasa konstruksi diatur dengan PP No.140 tahun 2000 yang ditetapkan tanggal 21 Desember 2000. Tujuan penerbitan PP No.140 Tahun 2000 adalah untuk meningkatkan efektivitas pengenaan pajak penghasilan dari usaha jasa konstruksi sesuai dengan prinsipprinsip yang dianut dalam Undang-Undang Pajak Penghasilan. Penggunaan PP No.140 Tahun 2000 dalam pelaksanaan kewajiban perpajakan sehubungan dengan penghasilan dari usaha jasa konstruksi berlangsung sampai dengan diterbitkannya PP No.51 Tahun 2008 yang ditetapkan tanggal 20
Juli 2008 dan diundangkan tanggal 23 Juli 2008. Penerbitan tersebut bertujuan untuk mengefektifkan penerimaan pajak negara dalam bidang usaha jasa konstruksi. Di dalam PP No.51 tahun 2008 terdapat perbedaan sifat dan tarif yang digunakan dalam perhitungan pajak penghasilan dari jasa konstruksi. Pengenaan pajak terhadap penghasilan dari jasa konstruksi bersifat final untuk semua jenis kualifikasi dengan tarif yang telah ditentukan.

Munculnya peraturan ini menimbulkan masalah dalam perlakuan pajak perusahaan karena ketentuan dalam peraturan ini berlaku surut terhadap pajak-pajak yang sudah disetor dan dilaporkan untuk periode 1 januari 2008 sedangkan peraturan dikeluarkan pada bulan Juli 2008. Oleh karena itu pemerintah mengeluarkan PP No.40 Tahun 2009 guna menyempurnakan PP No.51 Tahun 2008. Peraturan Pemerintah Nomor 40 Tahun 2009 diantaranya memuat ketentuan bahwa saat efektif berlakunya PP No.51 Tahun 2008 tidak dari 1 Januari 2008, melainkan untuk kontrak yang ditandatangani sejak tanggal 1 Agustus 2008.

Aspekperpajakan untukbidang usahajasa konstruksi memiliki ciri kekhususan karena sifatnya yang berbeda dengan bidang usaha lainnya. Dilihat dari sisi siklus operasinya yang memiliki waktu lebih dari satu tahun sehingga pendapatan dan bebannya pun dihitung secara khusus.

Jasa konstruksi adalah layanan jasa konsultasi perencanaan pekerjaan konstruksi, layanan jasa pelaksanaan pekerjaan konstruksi, dan layanan jasa konsultasi pengawasan pekerjaan konstruksi. Bidang usaha jasa konstruksi tersebut mencakup pekerjaan arsitektural, sipil, mekanikal, elektrikal dan atau tata lingkungan, masingmasing beserta kelengkapannya.

PT "X" Surabaya merupakan suatu usaha yang bergerak di bidang jasa konstruksi. 
Banyak perusahaan-perusahaan besar yang menggunakan jasa perusahaan untuk memperbaiki atau membangun gedung baru baik pihak swasta maupun instansi pemerintah.

\section{Kerangka Teoritik}

\section{Pengertian Pajak}

Menurut Soeparman Soemahamidjaja (Waluyo, 2011: 2), pajak adalah iuran wajib yang berupa uang atau barang yang dipungut oleh penguasa berdasarkan norma-norma hukum, guna menutup biaya produksi barang-barang dan jasa-jasa kolektif dalam mencapai kesejahteraan umum.

Menurut Rochmat Soemitro (Mardiasmo, 2011: 1), pajak adalah iuran rakyat kepada kas negara berdasarkan undang-undang (yang dapat dipaksakan) dengan tiada mendapatkan jasa timbal (kontraprestasi) yang langsung dapat ditunjukan dan yang digunakan untuk membayar pengeluaran umum. Definisi lain mengenai pajak adalah peralihan kekayaan dari pihak rakyat kepada kas negara untuk pembiayaan pengeluaran rutin dan surplusnya yang digunakan untuk public saving yang merupakan sumber utama untuk pembiayaan public investment.

Menurut S.I Djajadiningrat (Siti Resmi, 2011: 1), pajak sebagai suatu kewajiban menyerahkan sebagian dari kekayaan ke kas negara yang disebabkan oleh suatu keadaan, kejadian dan perbuatan yang memberikan kedudukan tertentu, tetapi bukan sebagai hukuman, menurut peraturan yang ditetapkan pemerintah serta dapat dipaksakan, tetapi tidak ada jasa timbal balik dari negara secara angsung, untuk memelihara kesejahteraan secara umum.

Menurut N.J Feldmann (Siti Resmi, 2011: 2), pajak adalah prestasi yang dipaksakan sepihak oleh dan terutang kepada penguasa (menurut norma-norma yang ditetapkan secara umum), tanpa adanya kontra prestasi dan semata-mata digunakan untuk menuntut pengeluaran-pengeluaran secara umum. Jadi, dapat disimpulkan bahwa pajak adalah iuran kepada Negara (yang dapat dipaksakan) yang terutang oleh yang wajib membayarnya menurut peraturanperaturan dan tidak mendapatkan prestasiprestasi kembali yang secara langsung dapat ditunjuk.

\section{Pengakuan Pendapatan Konstruksi Menurut PSAK No. 34}

Standar Akuntansi Keuangan secara khususmengaturtentangpengakuanpendapatan dan biaya kontrak dengan menerbitkan sebuah penyataan PSAK No. 34 tentang Akuntansi Kontrak Konstruksi. Tujuan PSAK No. 34 adalah untuk menggambarkan perlakuan akuntansi pendapatan dan biaya yang berhubungan dengan kontrak konstruksi. Oleh karena sifat dari aktivitas yang dilakukan pada kontrak konstruksi, tanggal saat aktivitas pada kontrak mulai dilakukan dan tanggal saat aktivitas tersebut diselesaikan biasanya jatuh pada periode akuntansi yang berlainan. Oleh karena itu, persoalan utama dari akuntansi kontrak konstruksi adalah alokasi pendapatan kontrak dan biaya kontrak pada periode dimana pekerjaan konstruksi tersebut dilaksanakan.

Menurut Rangkuti (2008) dalam Smith and Skousen, ada 2 metode dalam pengakuan pendapatan jasa konstruksi, yaitu :

1. Metode Kontrak Selesai

Metode kontrak selesai biasanya digunakan perusahaan yang mempunyai kontrak jangka pendek atau proyek yang memiliki resiko tidak dapat diestimasi secara andal. Pada metode ini, laba dilaporkan pada periode sewaktu proyek selesai.

\section{Metode Persentase Penyelesaian}

Metode pengakuan pendapatan persentase penyelesaian adalah metode pengakuan yang biasanya digunakan oleh perusahaan yang memiliki kontrak jangka panjang, dimana jangka waktunya 
lebih dari satu periode akuntansi. Metode ini mencerminkan prestasi kerja masa berjalan atas penyelesaian kontrak lebih dari satu periode akuntansi.

Metode persentase penyelesaian dalam pengakuan pendapatan kontrak akan memerlukan kondisi-kondisi yang harus dipenuhi sebagai berikut :

a. Total pendapatan kontrak harus dapat diukur secara andal;

b. Besar kemungkinan manfaat ekonomi yang berhubungan dengan kontrak tersebut akan tertagih dan mengalir ke perusahaan;

c. Baik biaya kontrak untuk menyelesaikan kontrak maupun tahap penyelesaian kontrak pada tanggal neraca dapat diukur secara andal;

d. Biaya kontrak yang dapat diatribusikan ke kontrak dapat diidentifikasi secara jelas sehingga biaya kontrak actual dapat dibandingkan dengan estimasi sebelumnya.

Dalam PSAK No. 34 (IAI, 2012, h.34.5), tentang pengakuan pendapatan dan biaya kontrak yaitu jika hasil kontrak konstruksi dapat diestimasi secara andal, maka pendapatan kontrak yang berhubungan dengan kontrak konstruksi diakui masingmasing sebagai pendapatan dan beban dengan memperhatikan tahap penyelesaian aktivitas kontrak pada tanggal akhir periode pelaporan.

\section{Pajak Penghasilan atas Jasa Konstruksi}

Pengertian Pajak Penghasian (PPh) berdasarkan Undang-Undang No. 36 Tahun 2008 adalah pajak yang dikenakan terhadap subjek pajak atas penghasilan yang diterima atau diperolehnya dalam satu tahun pajak atau suatu pungutan resmi yang ditujukan kepada masyarakat yang berpenghasilan yang diperolehnya dalam tahun pajak untuk kepentingan negara dan masyarakat dalam hidup berbangsa dan bernegara sebagai suatu kewajiban yang harus dilaksanakannya.
Dalam ketentuan perpajakan yang diatur dalam Peraturan Pemerintah No. 51 tahun 2008 sttd Peraturan Pemerintah No. 40 Tahun 2009 tentang Pajak Penghasilan dari Usaha Jasa Konstruksi dan Peraturan Menteri Keuangan Republik Indonesia Nomor 187/PMK.03/2008 tentang Tatacara Pemotongan, Penyetoran, Pelaporan, dan Penatausahaan Pajak Penghasilan atas Penghasilan dari Usaha Jasa Konstruksi. Jasa kontruksi adalah layanan jasa konsultasi perencanaan pekerjaan konstruksi, layanan jasa pelaksanaan pekerjaan konstruksi, dan layanan jasa konsultasi pengawasan pekerjaan konstruksi.

Pengguna Jasa adalah orang pribadi atau badan termasuk bentuk usaha tetap yang memerlukan layanan jasa konstruksi. Penyedia Jasa adalah orang pribadi atau badan termasuk bentuk usaha tetap, yang kegiatan usahanya menyediakan layanan jasa konstruksi baik sebagai perencana konstruksi, pelaksana konstruksi, dan pengawas konstruksi maupun sub-subnya. Nilai Kontrak Jasa Konstruksi adalah nilai yang tercantum dalam satu kontrakjasa konstruksi secara keseluruhan. Atas penghasilan dari usaha Jasa Konstruksi dikenakan Pajak Penghasilan yang bersifat final. Tarif Pajak Penghasilan yang bersifat final: (a) 2\% (dua persen) untuk Pelaksanaan Konstruksi yang dilakukan oleh Penyedia Jasa dengan kualifikasi usaha kecil; (b) 4\% (empat persen) untuk Pelaksanaan Konstruksi yang dilakukan oleh Penyedia Jasa yang tidak memiliki kualifikasi usaha; (c) 3\% (tiga persen) untuk Pelaksanaan Konstruksi yang dilakukan oleh Penyedia Jasa selain Penyedia Jasa sebagaimana dimaksud dalam huruf a dan huruf b; (d) 4\% (empat persen) untuk Perencanaan Konstruksi atau Pengawasan Konstruksi yang dilakukan oleh Penyedia Jasa yang memiliki kualifikasi usaha; dan (e) 6\% (enam persen) untuk Perencanaan Konstruksi atau Pengawasan Konstruksi yang dilakukan oleh Penyedia Jasa yang tidak memiliki kualifikasi usaha. 
Pajak penghasilan yang pengenaannya bersifat Final mengacu pada Pasal 4 ayat (2) Undang-Undang Pajak Penghasilan sebagai penghasilan tertentu yang pengenaan pajaknya diatur dalam peraturan pemerintah. Pertimbangan yang mendasari diberikannya perlakuan tersendiri antara lain adalah kesederhanaan dalam pemungutan pajak, keadilan dan pemerataan dalam pengenaan pajaknya serta perkembangan ekonomi dan moneter.

Dalam Pasal 4 PMK Nomor 187/ PMK. 03/2008 secara tegas menyatakan bahwa saat terutangnya $\mathrm{PPh}$ final atas jasa konstruksi terjadi pada saat pembayaran atau diterimanya pembayaran (cash basis).

Berdasarkan Pasal 5 ayat (2) Peraturan Pemerintah Nomor 51 Tahun 2008, disebutkan bahwa besarnya Pajak Penghasilan yang dipotong PPh Final Pasal 4 ayat (2) tersebut adalah sebesar jumlah pembayaran, tidak termasuk PPN, dikalikan tarif Pajak Penghasilan. Jumlah pembayaran dalam hal ini dapat disebut sebagai Dasar Pengenaan Pajak.

PPh Final Pasal 4 ayat (2) =

Tarif x (Nilai Kontrak atau Nilai Termin Pembayaran - PPN atas Nilai Kontrak atau Nilai Termin tersebut)

\section{Pemotong PPh Pasal 4 ayat 2 dan PPN}

Berdasarkan Pasal 5 ayat (1) Peraturan Pemerintah Nomor 51 Tahun 2008, disebutkan bahwa PPh Final Pasal 4 ayat (2) dipotong oleh Pengguna Jasa pada saat pembayaran jika Pengguna Jasa merupakan pemotong pajak, atau disetor sendiri oleh Penyedia Jasa jika Pengguna Jasa Bukan merupakan pemotong pajak.

Yang dimaksud dengan pemotong pajak adalah Badan Pemerintah, Subjek Pajak Badan Dalam Negeri, Bentuk Usaha Tetap, atau Orang Pribadi yang ditunjuk oleh Direktur Jenderal Pajak sebagai Pemotong Pajak Penghasilan.
Dengan demikian, bendaharawan pemerintah/pimpinan proyek/pimpinan kegiatan yang mengadakan pekerjaan jasa konstruksi wajib melakukan pemotongan PPh Pasal 4 ayat(2).

\section{Pajak Pertambahan Nilai}

Pajak Pertambahan Nilai adalah Pajak tidak Langsung yang dikenakan pada setiap pertambahaan nilai atau transaksi penyerahan barang dan atau jasa kena pajak dalam pendistribusiannya dari produsen dan konsumen. Disebut pajak tidak langsung karena tidak langsung dibebankan kepada penanggung pajak (konsumen) tetapi melalui mekanisme pemungutan pajak dan disetor oleh pihak lain (penjual). Transaksi penyerahannya bisa dalam bentuk jual-beli, pemanfaatan jasa, dan sewa-menyewa.

Pajak Pertambahan Nilai yang dikenakan dalam perusahaan jasa konstruksi adalah Pajak Pertambahan Nilai yang dikenakan atas pembelian bahan meterial yang digunakan dalam proses produksi perusahaan, Pajak Pertambahan Nilai yang diperoleh dari pembelian Barang Kena Pajak ini disebut Pajak Masukan serta Pajak Pertambahan Nilai atas penyerahan jasa konstruksi sebagai penyerahan Jasa Kena Pajak dan memungut Pajak Keluaran. Pajak Masukan yang telah dipungut dapat dikreditkan dengan Pajak Keluaran pada masa pajak yang sama tetapi jika belum dapat dikreditkan dengan PajakKeluaran pada masa yang sama maka dapat dikreditkan selambat-lambatnya 3 (tiga) bulan setelah berakhirnya masa pajak yang bersangkutan.

Pemungutan, penyetoran dan pelaporan PPN merupakan kewajiban dari Produsen atau Pedagang yang disebut Pengusaha Kena Pajak (PKP). Pengusaha Kena Pajak (PKP) adalah pengusaha yang melakukan penyerahan Barang Kena Pajak dan atau penyerahan Jasa Kena Pajak yang dikenakan pajak.

Atas kegiatan usaha jasa konstruksi di- 
kenakan PPN dengan tarif 10\% dari Dasar Pengenaan Pajak. Dasar Pengenaan Pajak dalam kegiatan usaha konstruksi adalah sebesar jumlah pembayaran tidak termasuk PPN.

Dalam pasal 11 ayat (1) Undang-Undang Pajak Pertambahan Nilai, Pajak Pertambahan Nilai terutang pada saat penyerahan Jasa Kena Pajak itu dilakukan, meskipun pelunasan pembayaran jasa konstruksi tersebut belum diterima oleh Kontraktor.

Bukti pungutan pajak atas penyerahan Jasa Kena Pajak berupa faktur pajak. Saat pembuatan faktur pajak menurut PER - 24/PJ/2012 faktur pajak harus dibuat pada: (a) Saat penyerahan Barang Kena Pajak dan/atau Jasa Kena Pajak; (b) Saat penerimaan pembayaran dalam hal penerimaan pembayaran terjadi sebelum penyerahan Barang Kena Pajak dan/atau sebelum penyerahan Jasa Kena Pajak; (c) Saat penerimaan pembayaran termin dalam hal penyerahan sebagian tahap pekerjaan; (d) Saat PKP rekanan menyampaikan tagihan kepada Bendahara Pemerintah sebagai Pemungut Pajak Pertambahan Nilai; atau (e) Saat lain yang diatur dengan atau berdasarkan Peraturan Menteri Keuangan.

Kerangka pemikiran yang mendasari penelitian ini dapat dilihat pada Gambar 1 (Kerangka Pemikiran).

\section{Pembahasan}

Pendapatan usaha PT "X" Surabaya terdiri atas pendapatan jasa konstruksi dan pendapatan dari luar jasa konstruksi yaitu dari pengadaan barang. Oleh karena itu dalam laporan laba rugi akan disajikan secara terpisah untuk penghasilan yang dikenakan PPh Final dan yang tidak final.

Pendapatan dari jasa konstruksi seperti pada tanggal 10 Juli 2013 mendapatkan proyek dari Pekas Mako "Y" untuk kontrak pengadaan konstruksi perbaikan sedang mess TD BA/TA Gunung Semeru "Y" dengan nilai kontrak sebesar Rp 1.310.700.000 (include PPN dan PPh).

Pekas Mako "Y" bersedia membayar uang

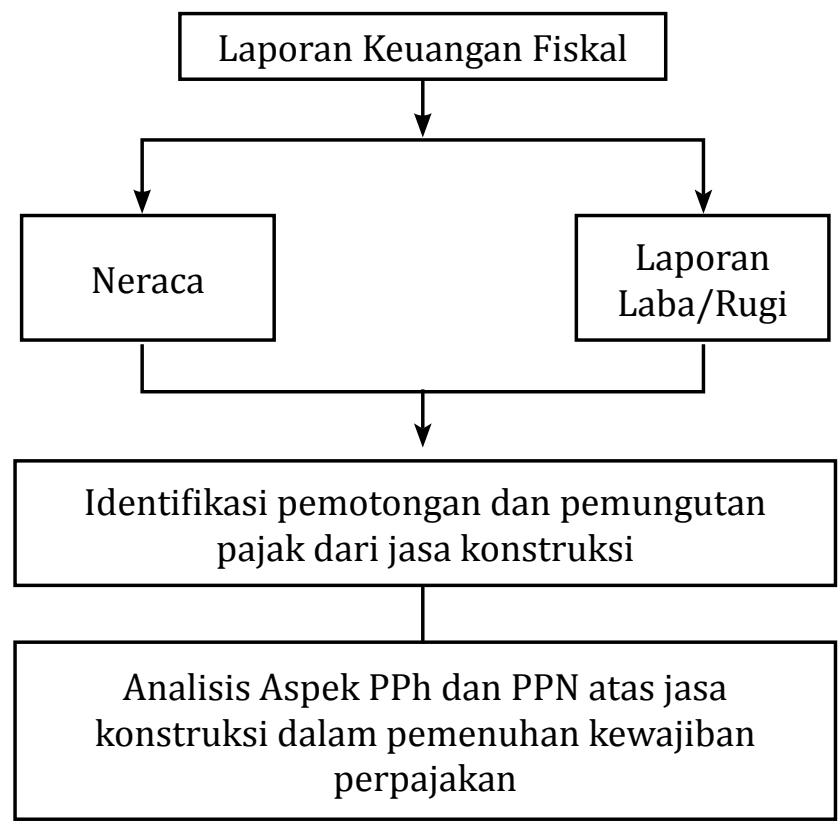

Gambar 1. Kerangka Pemikiran 
muka sebesar 20\% (dua puluh persen) dari harga kontrak. Pengembalian uang muka tersebut akan diperhitungkan pada saat pembayaran angsuran dan harus lunas pada saat pekerjaan mencapai 100\% (seratus persen).

Pekas Mako "Y" bersedia bersedia membayar harga barang/jasa tersebut secara berangsur-angsur sesuai dengan kemajuan pekerjaan sebagai berikut :

1. Termin I sebesar 35\% (tiga puluh persen) dari harga kontrak atau sebesar Rp 458.745.000 dikurangi pengembalian uang muka sebesar Rp 131.070.000 (0,5 $\mathrm{x}$ uang muka) $=\mathrm{Rp} 327.675 .000$ jika prestasi pekerjaan telah mencapai $40 \%$ (empat puluh persen).

2. Termin II sebesar 35\% (tiga puluh lima persen) dari harga kontrak atau sebesar Rp 458.745.000 dikurangi pengembalian uang muka sebesar $\mathrm{Rp}$ 131.070.000 $(0,5 \times$ uang muka $)=R p 327.675 .00$ jika prestasi pekerjaan telah mencapai $75 \%$ (tujuh puluh lima persen).

3. Termin III sebesar $30 \%$ (tiga puluh persen) dari harga kontrak atau sebesar Rp 393.210.000 jika prestasi pekerjaan telah mencapai $100 \%$ (seratus persen).

Metode pengakuan pendapatan yang digunakan oleh PT "X" Surabaya adalah metode persentase penyelesaian. Dalam pencatatan akuntansi, PT "X" Surabaya menganut sistem accrual basis.

Pemilihan metode pengakuan pendapatan secara tepat akan mempengaruhi perolehan laba dalam suatu periode akuntansi. Pada umumnya perusahaan mengakui pendapatannya pada saat adanya realisasi dari suatu transaksi. Namun lain halnya dengan perusahaan konstruksi, pendapatan diakui berdasarkan termin sesuai dengan nilai prestasi yang telah dicapai oleh perusahaan (berdasarkan metode persentase penyelesaian) menurut perjanjian kontrak.

Atas penghasilan dari usaha jasa konstruksi terutang PPh Pasal 4 ayat (2) pada saat pembayaran uang muka atau termin. Sedangkan Pajak Pertambahan Nilai terutang pada saat penyerahan Jasa Kena Pajak.

PT "X" Surabaya sebagai Wajib Pajak, pada saat menerima pembayaran uang muka maupun termin akan dipotong PPh Pasal 4 ayat 2 dan dipungut PPN oleh pihak pemberi kerja, dalam hal ini adalah Pekas Mako "Y". Kewajiban Pekas Mako "Y" adalah menyetorkan pemotongan PPh Pasal 4 ayat 2 dan PPN ke bank persepsi. Sedangkan PT "X" Surabaya berhak menerima bukti pembayaran pajak berupa Surat Setoran Pajak (SSP) lembar pertama dan bukti potong PPh Pasal 4 ayat 2.

Tabel 1. Daftar Pembayaran Jasa Pelaksanaan Konstruksi

\begin{tabular}{|l|r|r|}
\hline Pembayaran & $\begin{array}{c}\text { Jumlah Bruto } \\
\text { (Include PPN) }\end{array}$ & \multicolumn{1}{c|}{ DPP } \\
\hline Uang Muka & 262.140 .000 & 238.309 .091 \\
\hline Termin I & 327.675 .000 & 297.886 .364 \\
\hline Termin II & 327.675 .000 & 297.886 .364 \\
\hline Termin III & 393.210 .000 & 357.463 .637 \\
\hline \multicolumn{1}{|c|}{ TOTAL } & $\mathbf{1 . 3 1 0 . 7 0 0 . 0 0 0}$ & $\mathbf{1 . 1 9 1 . 5 4 5 . 4 5 6}$ \\
\hline
\end{tabular}

Sumber : Internal Perusahaan 
Sebagai bukti bahwa Bendaharawan telah memotong dan menyetorkan PPh Pasal 4 ayat (2) atas penghasilan dari usaha jasa konstruksi adalah dengan memberikan :

a. Bukti Pemotongan / Pemungutan PPh

Pasal 4 ayat (2) atas Penghasilan dari

Usaha Jasa Konstruksi;dan

b. Surat Setoran Pajak.

Dalam menentukan perhitungan $\mathrm{PPh}$ Badan atas usaha jasa konstruksi, PT "X" Surabaya berkewajiban untuk menyusun laporan laba rugi secara terpisah untuk penghasilan yang dikenakan $\mathrm{PPh}$ final dan yang tidak final. Laporan laba rugi untuk penghasilan yang dikenakan PPh final tidak perlu dilakukan koreksi fiskal. Sementara laporan laba rugi untuk penghasilan usaha yang berasal dari pengadaaan barang maka perhitungan $\mathrm{PPh}$ mengikuti ketentuan Pasal 17 UU PPh dengan tarif sebesar 25\%, dikarenakan peredaran bruto perusahaan telah melebihi 4,8 Milyar.

Perhitungan PPh Final atas pendapatan jasa konstruksi tahun 2013 dihitung dari jumlah pendapatan dikalikan dengan tarif $3 \%$ tanpa ada koreksi fiskal sebesar Rp 922.539.707. Penghasilan yang dikenakan PPh Final dilaporkan dalam SPT Tahunan 1771 lampiran IV pada bagian A : PPh Final no. 8 untuk jenis penghasilan dari imbalan jasa konstruksi.

Pendapatan perusahaan yang berasal dari pengadaan barang pada tabel 1.5 maka perhitungan pajak penghasilan badan mengacu pada pasal 17 UU PPh sebesar Rp 861.500 dikurangi dengan kredit pajak PPh Pasal 22 yang dipungut oleh bendaharawan pemerintah sebesar Rp 656.438 sehingga PPh Kurang Bayar (Pasal 29) sebesar Rp 205.062. Penghasilan dari pengadaan barang dilaporkan dalam SPT Tahunan 1771 Induk dan kredit PPh Pasal 22 dilaporkan dalam lampiran 1771-III. Namun dalam penyetoran PPh Kurang Bayar, PT."X" Surabaya melakukan penyetoran dengan kode akun pajak 411124 dan kode jenis setoran 104 dimana kode jenis setoran ini untuk jenis PPh Pasal 23. Kode akun pajak yang seharusnya adalah 411126 untuk PPh Pasal 25/29 Badan dan kode jenis setoran 200 untuk Tahunan PPh Badan. Dengan kekeliruan ini dalam kode penyetoran pajak ini, sebaiknya PT."X" Surabaya segera membuat permohonan pemindahbukuan atas pajak yang telah dibayarkan.

Jenis usaha jasa konstruksi merupakan objek Pajak Pertambahan Nilai. Dalam hal ini apabila perusahaan melakukan penyerahan Barang Kena Pajak dan atau Jasa Kena Pajak akan dikenakan PPN. Berdasarkan KMK563/KMK.03/2003 bahwa bendaharawan pemerintah baik pusat maupun daerah adalah pemungut PPN. Sehingga dalam hal ini, pemungutan PPN dilakukan oleh Pekas Mako "Y".

Tabel 2. Daftar Pemotongan dan Pemungutan Pajak Atas Pelaksanaan Konstruksi

\begin{tabular}{|l|r|r|}
\hline \multicolumn{1}{|c|}{ Pembayaran } & \multicolumn{1}{|c|}{$\begin{array}{c}\text { PPN } \\
\mathbf{1 0 \%}\end{array}$} & PPh Pasal 4(2) 3\% \\
\hline Uang Muka & 23.830 .909 & 7.149 .273 \\
\hline Termin I & 29.788 .636 & 8.936 .591 \\
\hline Termin II & 29.788 .636 & 8.936 .591 \\
\hline Termin III & 35.746 .363 & 10.723 .910 \\
\hline TOTAL & $\mathbf{1 1 9 . 1 5 4 . 5 4 5}$ & $\mathbf{3 5 . 7 4 6 . 3 6 5}$ \\
\hline
\end{tabular}

Sumber : Internal Perusahaan 
Dalam hal pembuatan Faktur Pajak mengacu pada PER - 24/PJ/2012 dimana faktur pajak harus dibuat pada saat PKP rekanan menyampaikan tagihan kepada Bendaharawan Pemerintah sebagai Pemungut Pajak Pertambahan Nilai. Sedangkan bukti bahwa Bendaharawan telah memungut PPN atas jasa konstruksi adalah berupa :
a. Faktur Pajak ; dan
b. Surat Setoran Pajak (SSP) PPN Lembar 1.

Pemungutan PPN dilakukan dengan cara sebagai berikut:

i. Pengusaha Kena Pajak Rekanan (PKP Rekanan) menerbitkan Faktur Pajak dan SSP pada saat menyampaikan tagihan kepada Bendaharawan, baik untuk sebagian maupun seluruh pembayaran. Dalam hal pembayaran diterima sebelum penagihan, atau sebelum penyerahan Barang Kena Pajak, maka Faktur Pajak wajib diterbitkan pada saat pembayaran

Tabel 3. Pencatatan atas penerimaan Uang muka dan Termin

\begin{tabular}{|l|r|r|}
\hline \multicolumn{1}{|c|}{ Jurnal } & \multicolumn{1}{|c|}{ Debit } & \multicolumn{1}{c|}{ Kredit } \\
\hline Saat UangMuka : & & \\
Kas & 231.159 .818 & \\
PPh Pasal 4 (2) & 7.149 .273 & \\
PPN Pemungut & 23.830 .909 & \\
$\quad$ Uang Muka Kontrak & & 238.309 .091 \\
$\quad$ PPN Keluaran & & 23.830 .909 \\
\hline Saat Termin I: & & \\
Kas & 288.949 .773 & \\
PPh Pasal 4 (2) & 8.936 .591 & \\
PPN Pemungut & 29.788 .636 & \\
Uang Muka Kontrak & 119.154 .545 & \\
$\quad$ Pendapatan & & 417.040 .909 \\
$\quad$ PPN Keluaran & & 29.788 .636 \\
\hline Saat Termin II: & & \\
Kas & & \\
PPh Pasal 4 (2) & 28.936 .789 .636 & \\
PPN Pemungut & 119.154 .545 & \\
Uang Muka Kontrak & & \\
$\quad$ Pendapatan & & \\
PPN Keluaran & & \\
\hline Saat Termin III: & & \\
\hline Kas & & \\
PPh Pasal 4 (2) & & \\
PPN Pemungut & & \\
$\quad$ Pendapatan & & \\
$\quad$ PPN Keluaran & & \\
\hline
\end{tabular}

Sumber : Internal Perusahaan 
diterima.

ii. Faktur Pajak dibuat rangkap 3(tiga):

- Lembar ke 1: untuk Bendaharawan

- Lembar ke 2: untuk arsip PKP Rekanan

- Lembar ke 3: untuk dilampirkan pada SPT Masa PPN Bagi Pemungut (Formulir 1107 PUT).

PPN Masukan yang telah dibayar oleh PT. "X" Surabaya yang timbul karena adanya pembelian Barang Kena Pajak. Pembelian barang tersebut tersebut yaitu barang yang akan digunakan dalam proses pekerjaan jasa konstruksi, setiap transaksi pembelian, perusahaan selaku Pengusaha Kena Pajak harus menerima lembar asli dari Faktur Pajak dari perusahaan yang melakukan penyerahan Barang Kena Pajak atau Jasa Kena Pajak. Faktur Pajak yang dibuat oleh perusahaan yang melakukan penyerahan Barang Kena Pajak atau Jasa Kena Pajak harus sesuai ketentuan pajak yang berlaku, sehingga pajak jumlah pajak yang tercatat didalam nya dapat dikreditkan dengan dengan Pajak Keluarannya.

Berdasarkan analisa transaksi bahwa semua penyerahan jasa konstruksi dilakukan kepada pemungut PPN sehingga dalam pelaporan SPT Masa PPN PT "X" mengalami lebih bayar sampai akhir tahun 2013. Hal ini bisa dilihat pada Tabel 6 .

Data perolehan BKP/JKP dan PPN Masukan dilaporkan dalam SPT Masa PPN Formulir 1111 B2 dan Formulir 1111 AB. PPN Lebih bayar akan nampak pada SPT Masa PPN Induk sebesar Rp 1.252.334.868. Pada laporan keuangan (Neraca), kelebihan PPN dicatat sebagai Uang Muka PPN. PT "X"

Tabel 4.Laporan Laba Rugi

Untuk Tahun Yang Berakhir 31 Desember 2013

(dalam Rupiah)

\begin{tabular}{|l|c|}
\hline Pendapatan & $\mathbf{3 0 . 7 5 1 . 3 2 3 . 5 7 6}$ \\
Ueban Pokok Penjualan : & \\
Transportasi dan survey & 9.675 .535 .150 \\
Administrasi dan umum proyek & 774.219 .055 \\
Pemakaian Material & 172.364 .000 \\
Beban Pokok Penjualan & 16.300 .191 .600 \\
Laba Kotor & $\mathbf{2 6 . 9 2 2 . 3 0 9 . 8 0 5}$ \\
Total Beban usaha & $\mathbf{3 . 8 2 9 . 0 1 3 . 7 7 1}$ \\
Laba Usaha & $\mathbf{8 9 4 . 5 7 9 . 0 8 5}$ \\
& 2.934 .434 .686 \\
Pendapatan (Beban) di Luar Usaha : & \\
Pendapatan jasa giro (Net) & 7.590 .183 \\
Laba bersih Sebelum Pajak & 2.942 .024 .869 \\
PPh Konstruksi Final & $\mathbf{9 2 2 . 5 3 9 . 7 0 7}$ \\
Laba Bersih Setelah Pajak & 2.019 .485 .162 \\
\hline
\end{tabular}

Sumber : Internal Perusahaan 
Tabel 5.

Laporan Laba Rugi

Untuk Tahun Yang Berakhir 31 Desember 2013

(dalam Rupiah)

\begin{tabular}{|l|c|}
\hline Pendapatan & 21.881 .280 \\
Upah Kerja & 1.852 .140 \\
Transportasi dan survey & 875.250 \\
Administrasi dan umum proyek & 278.450 \\
Pemakaian Material & 12.075 .510 \\
Beban Pokok Penjualan & $\mathbf{1 5 . 0 8 1 . 3 5 0}$ \\
Laba Kotor & $\mathbf{6 . 7 9 9 . 9 3 0}$ \\
Total Beban usaha & $\mathbf{3 . 3 5 3 . 5 0 0}$ \\
Laba Usaha & $\mathbf{3 . 4 4 6 . 4 3 0}$ \\
& \\
Laba bersih Sebelum Pajak & $\mathbf{3 . 4 4 6 . 0 0 0}$ \\
PPh Terutang (tarif Pasal 17) & 861.500 \\
PPh Pasal 22 & 656.438 \\
PPh Pasal 29 & 205.062 \\
Laba Bersih Setelah Pajak & $\mathbf{2 . 5 8 4 . 5 0 0}$ \\
\hline
\end{tabular}

Sumber : Internal Perusahaan

Tabel 6. PPN Masukan yang Dapat Diperhitungkan (dalam Rupiah)

\begin{tabular}{lcc}
\hline \multicolumn{1}{c}{ Keterangan } & DPP & PPN \\
\hline $\begin{array}{l}\text { Perolehan BKP/JKP dari } \\
\text { Dalam Negeri Yang PM-nya } \\
\text { dapat dikreditkan (Masa } \\
\text { Desember 2013) }\end{array}$ & 123.812.948 & \\
Kompensasi kelebihan PPN & 12.381 .295 \\
Masa Pajak sebelumnya & \\
$\begin{array}{l}\text { Jumlah Pajak Masukan } \\
\text { yang dapat diperhitungkan }\end{array}$ & \\
\end{tabular}

Sumber : Internal Perusahaan 
Surabaya memiliki hak melakukan restitusi pajak atau kompensasi pada masa pajak berikutnya apabila terjadi Lebih Bayar atas Pajak Pertambahan Nilai. Namun hal ini belum dilakukan karena perusahaan akan dilakukan pemeriksaan pajak.

\section{Simpulan dan Saran}

PT "X" Surabaya sebagai Wajib Pajak telah memenuhi serta mentaati semua ketentuan dan peraturan yang dibuat oleh pemerintah dalam memenuhi kewajiban perpajakannya terkait Pajak Penghasilan atas jasa usaha konstruksi dan PPN sesuai dengan ketentuan perpajakan yang berlaku.

PT. "X" Surabaya merupakan penyedia jasa atas pelaksana jasa konstruksi, dimana setiap kegiatan pelaksanaan konstruksi dikenakan pajak penghasilan pasal 4 ayat 2 sebesar 3\% dari jumlah bruto. Selain itu penghasilan dari jasa konstruksi dikenakan Pajak Pertambahan Nilai (PPN) sebesar 10\% dari jumlah dasar pengenaan pajaknya.

Keterbatasan penelitian ini adalah transaksi jasa kontruksi yang dilakukan perusahaan semuanya dilakukan pada bendaharawan pemerintah dan hanya menganalisis aspek perpajakan dari sisi pendapatan jasa konstruksi.

Saran untuk penelitian selanjutnya adalah memperluas transaksi penyerahan jasa konstruksi yang tidak hanya dilakukan kepada bendaharawan pemerintah namun juga dilakukan kepada perusahaan nonbendaharawan pemerintah sehingga akan nampak perbedaan dalam menjalankan pemenuhan kewajiban perpajakannya.

\section{Daftar Pustaka}

Febriyanti, S. 2014. Evaluasi Penerapan Pemotongan Pajak Penghasilan Pasal 23 Atas Jasa Perawatan, Pemeliharaan Dan Perbaikan Kendaraan Pada CV. Anugerah Multi Sarana. Jurusan Akuntansi STIE MDP.

Fharadilah Putri, A. 2013.Analisis Perhitungan, Pencatatan, dan Pelaporan Pajak Pertambahan Nilai Pada PT Badak NGL Bontang (Doctoral Dissertation).

Geruh, M. R. 2013. Penerapan Akuntansi Terhadap Pajak Pertambahan Nilai Pada Pengusaha Kena Pajak. Jurnal Riset Ekonomi, Manajemen, Bisnis Dan Akuntansi, Volume 1, Nomor 3.

IAI, I. A. 2012. Pernyataan Standar Akuntansi Keuangan (Psak). Jakarta: Salemba Empat.

Icuk Rangga Bawono, M. N. (2012). Perpajakan Untuk Bendaharawan. Yogyakarta: UPP STIE YKPN.

KMK Nomor 563/KMK.03/2003 Tanggal 24 Desember 2003 Tentang Penunjukan Bendahara Pemerintah dan Kantor Perbendaharaan dan Kas Negara Untuk Memungut, Menyetor dan Melaporkan PPN dan PPnBM Beserta Tata Cara Pemungutan, Penyetoran dan Pelaporannya

Mardiasmo. 2011. Perpajakan Edisi Revisi 2011. Yogyakarta: Andi Offset.

Nazir, M. 2005. Metode Penelitian. Bogor: Ghalia Indonesia.

Nelwan, T. S. 2013. Evaluasi Pemotongan, Penyetoran Dan Pelaporan PPh Pasal 23 Pada Bank Prisma Dana Manado. Jurnal Riset Ekonomi, Manajemen, Bisnis dan Akuntansi, Volume 1, Nomor 3. 
Republik Indonesia. Peraturan Pemerintah No. 51 Tahun 2008 sebagaimana telah diubah dengan Peraturan Pemerintah No.40 Tahun 2009 tentang Pajak Penghasilan atas penghasilan dari usaha konstruksi.

Republik Indonesia. Peraturan Menteri Keuangan No.187/PMK.03/2008 tentang Tata Cara Pemotongan, Penyetoran, Pelaporan dan Penatausahaan Pajak Penghasilan atas Penghasilan dari Usaha Jasa Konstruksi.

Republik Indonesia. Undang-Undang No. 36 Tahun 2008 tentang Pajak Penghasilan.

Republik Indonesia. Undang-Undang No. 42 Tahun 2009 tentang Pajak Pertambahan Nilai dan Pajak Penjualan Barang Mewah.

Resmi, S. 2011. Perpajakan Teori dan Kasus (Vol. 6). Yogyakarta: Salemba Empat.

Sukardji, U. 2008. Pemungut Pajak Pertambahan Nilai. Jakarta: Rajawali Pers.

Skousen, Stice. 2009. Akuntansi Keuangan Intermediate. Edisi keenam belas buku satu, Terjemahan, Jakarta: Penerbit Salemba Empat.

Waluyo. 2012. Akuntansi Pajak. Vol. 4. Yogyakarta: Salemba Empat. 
